\title{
BIOGEOCENOLOGY, GEOBOTANY AND PHYTOCENOLOGY
}

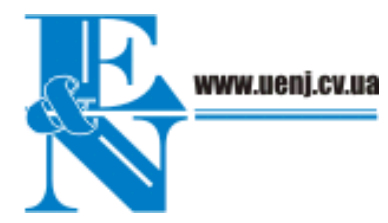

UDK 631

\author{
A. V. Bogovin $\square \quad$ Dr. Sci. (Agric.), Professor
}

National Research Centre "Institute of Agriculture of the NAAS”, Mashinostroitelei str., 2-b, Chabany, Kyiv region, Ukraine, 08162

\section{CONTRIBUTION OF NATIONAL SCIENTIFIC CENTER "INSTITUTE OF AGRICULTURE NAAS" IN THE DEVELOPMENT OF ECOLOGIC-BIOLOGICAL AND AGROTECHNICAL BASES OF MEADOW SCIENCE IN UKRAINE}

\begin{abstract}
In this article the history of the formation of the National Scientific Center "Institute of Agriculture NAAS" of Ukrainian Academy of Agrarian Sciences of Ukraine is briefly presented. It is noted that it started its existence in 1900 as agrochemical laboratory of Kiev Society Agriculture and Agricultural Industry and in 1935 it already became multidisciplinary and influential research institution in problems of agriculture, that was widely recognized in Ukraine, Soviet Union and far abroad. After establishing of the Department fodder production in it in 1944, then the Department of Meadow Science and now the Department of forage production and Meadow Science, the Institute has also done much in this field of knowledge.

Under the methodological guidance and direct participation of Institute in 1957-1961 years, simultaneously with the examination of soil cover in Ukraine, continuous large-scale geobotanical survey and culture-technical examination of hay-pasture lands had been done and regarding to each farm type plans and cartograms of their improvements were made and have been widely used during planning and implementation of works on improving the efficiency of the use of country's land resources and valuation of soil.

The Institute investigated the natural essence of different types of meadows and developed theoretical and practical problems of their flora, ecology, geography, classification, structure and a wide range of measures to improve their ecological and biological, economic and environmental values. It comprehensively elucidated the potential properties of perennial grasses and annual forage crops as representatives of primary and the most determinative material-energetic link of natural and anthropogenically transformed ecosystems, their degree of biological compatibility in coenoses and on the basis of consideration of coenobiotical complementarity made selection and zoning of their mixtures for different geographical areas of countries, environmental growing conditions and economic purpose.

A great work has been carried out to develop agrotechnics for cultivation of fodder crops, systems of their fertilization, irrigation, use of biological nitrogen in meadow science, principles of optimizing of spatial and functional organization of agricultural landscapes and ways of reproduction in their composition of permanent herbaceous ecosystems, as stabilizing elements of natural and man-made systems.

The scientific basis for the creation and an effective use of irrigated and unirrigated pasture was developed and for the first time in Ukraine, former Soviet Union and in the world the technology of
\end{abstract}

Tel.: +38044-526-71-26. E-mail: zemledel@mail.ru

DOI: $10.15421 / 031501$

ISSN 1726-1112. Ecology and noospherology. 2015. Vol. 26, no. 1-2 
combined use of irrigated pasture with combination of large groups (20-25 ha in one array) with a daily potion grazing of high yielding cows (4,5-5 thousand $\mathrm{kg}$ of milk.) by large herds (up to 500-600 heads in the herd) was perfected and implemented in production andduring the XII International Congress on Meadow Science held in Moscow in 1974, received the highest rating from world leading meadow.

The methodical base of systematic study of biotic systems and their biodiversity through extensive involvement in the research process of different physiognomic, floristry, individualistic and functionally-group ratings of biomorphological, trophic, destructive, ecological and many other important system properties was significantly expanded.

Also the participation in international scientific congresses and symposia on meadow science, that were held in foreign countries, and representation of employees in their governing bodies had been shown in the article.

Keywords: meadow science, natural and man-made lukopasovyschni ecosystems, biodiversity, productivity, function-group methods research environment.

\section{УДК 631 А. В. Боговин д-р с.-х. наук, проф.}

Начиональный научный иентр «Институт земледелия НААН», ул. Машиностроителей, 2-б, Чабаны, Киевская обл., Украина, 08162, тел.: + 38044-526-71-26, e-mail: zemledel@mail.ru

\section{ВКЛАД НАЦИОНАЛЬНОГО НАУЧНОГО ЦЕНТРА «ИНСТИТУТ ЗЕМЛЕДЕЛИЯ НААН» В РАЗВИТИЕ ЭКОЛОГО-БИОЛОГИЧЕСКИХ И АГРОТЕХНИЧЕСКИХ ОСНОВ ЛУГОВОДСТВА В УКРАИНЕ}

Аннотация. В статье кратко изложена история становления Национального научного центра «Институт земледелия НААН» Национальной академии аграрных наук Украины. Начавший свое существование в 1900 г. с агрохимической лаборатории, он уже к 1935 г. превратился в многопрофильное влиятельное в области земледелия научно-исследовательское учреждение в Украине. С образованием в 1944 г. в нем отдела кормопроизводства, потом луговодства и ныне кормопроизводства и луговодства он много сделал и в этой отрасли знаний.

Под методическим руководством и непосредственном участии института в 1957-1961 гг. одновременно со сплошным обследованием почвенного покрова Украины, было осуществлено крупномасштабное геоботаническое и культуртехническое обследование природных кормовых угодий и для всех хозяйств республики составлены типы лугов и картограммы их улучшения, которые сыграли большую роль в планировании и реализации работ по повышению их природно-ресурсного потенциала.

В институте исследованы природная сущность различных типов лугов, теоретические и практические проблемы их флоры, экологии, географии, классификации и разработан широкий комплекс технологических приемов повышения их эколого-биологической, хозяйственной и природоохранной ценности.

Для разных типов лугов и зон Украины подобраны лучшие виды трав и их травосмеси, разработаны системы удобрения, орошения, использования в луговодстве биологического азота, принципы улучшения сбалансированности территориально-функциональной организации аграрных ландшафтов путем увеличения в их составе стабилизирующих элементов на базе создания зональных эколого-биологических систем с высокой самовосстановительной способностью.

Значительное внимание уделено изучению биоразнообразия природных и антропогенных экосистем и расширена методическая база их изучения с широким использованием физиогномических, флористико-индивидуалистических и функциональногрупповых методов оценок биоморфологических, ритмических, экологических и других свойств биотических комплексов, разработке эффективных путей сбалансированного их использования и охраны. Показано участие разработчиков в Международных конгрессах и симпозиумах по луговодству, состоявшихся в странах дальнего зарубежья.

Ключевые слова: луговодство, природные и антропогенные лугопастбищные экосистемы, биоразнообразие, продуктивность, функиионально-групповые методы изучения, окружающая среда. 
Національний науковий центр «Інститут Землеробства НААН», вул. Машинобудівників, 2-б, Чабани, Київська обл., Україна, 08162, тел.:+38044-526-71-26, e-mail: zemledel@mail.ru

\title{
ВНЕСОК НАЦІОНАЛЬНОГО НАУКОВОГО ЦЕНТРУ «IНСТИТУТ ЗЕМЛЕРОБСТВА НААН» У РОЗВИТОК ЕКОЛОГО-БІОЛОГІЧНИХ ТА АГРОТЕХНІЧНИХ ОСНОВ ЛУКІВНИЦТВА В УКРАЇНІ
}

\begin{abstract}
Анотація. У статті коротко подана історія становлення Національного наукового центру «Інститут землеробства НААН». Вказано, що започаткувавши своє існування у 1900 р. 3 агрохімічної лабораторії Київського Товариства сільського господарства й сільськогосподарської промисловості, він вже до 1935 р. перетворився в багатопрофільну впливову з проблем землеробства науково-дослідну установу, широко визнану в Україні, Союзі та за їх межами. 3 утворенням в ньому в 1944 р. відділу кормовиробництва, потім луківництва і нині кормовиробництва і луківництва інститут багато зробив і у цій галузі знань.

Під методичним керівництвом і за безпосередньої участі інституту в 1957-1961 pp. одночасно з обстеженням грунтового покриву в Україні здійснено суцільне великомасштабне геоботанічне та культуртехнічне обстеження сінокісно-пасовищних угідь, стосовно до кожного господарства складено плани типів та картограми їх поліпшення, які широко були використані при плануванні та реалізації робіт з підвищення ефективності використання земельних ресурсів країни, бонітування грунтів.

В інституті досліджена природна сутність різних типів лук та розроблено теоретичні й практичні проблеми їх флори, екології, географії, класифікації, структури та широкий комплекс технологічних заходів підвищення їхньої еколого-біологічної, господарської та природоохоронної цінності.

Велика робота проведена з розробки агротехніки вирощування кормових культур, систем їх удобрення, зрошення, використання в луківництві біологічного азоту, принципів оптимізації просторово-функціональної організації агроландшафтів і способів відтворення в їх складі постійних трав'янистих екосистем як стабілізуючих елементів природно-антропогенних комплексів.

Ключові слова: луківництво, природні й антропогенні лукопасовищні екосистеми, біорізноманіття, продуктивність, функиіонально-групові методи досліджень, довкілля.
\end{abstract}

Національний науковий центр «Інститут землеробства НААН» Національної академії аграрних наук України, почавши своє існування у 1900 р. 3 агрохімічної лабораторії Київського Товариства сільського господарства та сільськогосподарської промисловості (Sayko, 2000), вже до 1935 р., сконцентрувавши у своєму складі сузір'я талановитих учених (Г. Г. Махов, О. І. Душечкін, Г. М. Самбур, Н. Б. Вернандер, М. М. Годлін, О. М. Вишинський, П. О. Дмитренко, пізніше В. М. Лебедєв, О. С. Скорозумов, В. О. Пастушенко та ін.), перетворився в багатопрофільну й впливову науково-дослідну установу республіканського масштабу, широко визнану в Україні, колишньому Союзі та за його межами.

Інститут (з 1935 р. - Український НДІ соцземлеробства Наркозему України, 3 1956 р. - Український НДІ землеробства МСГ УРСР, 31992 р. - Інститут землеробства Української академії аграрних наук, а 32006 р. - Національний науковий центр «Інститут землеробства НААН» Національної академії аграрних наук України), в той час маючи в усіх зонах України широку мережу дослідних станцій 3 вивчення корінних питань землеробства й агрономії він заслужено зайняв лідируюче положення в країні 3 зазначених проблем, беззмінно здійснював координацію досліджень, брав активну участь і вагомо впливав на формування землеробської політики в агропромисловому секторі республіки.

Одночасно інститут у ролі керівника й безпосереднього виконавця здійснив велику й унікальну за значенням спочатку вибірково на регіональному рівні (40-50-ті pp. ХХ ст.), а пізніше (1956-1961рр.) здійснив суцільне великомасштабне обстеження 
грунтового покриву країни як важливого ії ресурсного потенціалу та геоботанічне й культуртехнічне обстеження природних сінокосів і пасовищ - невід'ємної складової кормової бази тваринництва.

Результати виконання першої черги зазначених робіт були покладені в основу проектування Південноукраїнського та Краснознам'янського магістральних каналів зони зрошення Каховської ГЕС й розробки іригаційної мережі та системи землеробства на зрошуваних землях Півдня України, а 1956-1961 pp. удосконалення районування сільськогосподарського виробництва та розробки систем землеробства й кормовиробництва в межах кожного господарства країни.

Значний внесок на різних етапах організаційного становлення інституту й розвитку в ньому наукових досліджень зробили директори: спочатку П. Р. Сльозкін, а потім Г. І. Жуков (1928-1932 рр.), О. І. Подвиг (1932-1935 рр.), к. с.-г. наук П. І. Глухов (1935-1937 рр.), к. с.-г. наук М. Т. Коновалов (1937-1941 і 1945-1956 рр.), проф. Г. Г. Махов (1942-1944 рр.), д-р с.-г. наук, проф. Ф. П. Юхимчук (1956-1968 рр.), д-р с.-г. наук В. М. Євмінов (1968-1983 рр.), д-р с.-г. наук, проф., акад. НААН В. Ф. Сайко (1983-2011 рр.) і 32011 р. успішно очолює д-р с.-г. наук, проф., чл.-кор. НААН В. Ф. Камінський.

3 утворенням у 1944 р. в установі відділу кормовиробництва (потім луківництва, а нині кормовиробництва і луківництва) та приходом з Харківського інституту рослинництва на посаду завідувача вже досвідченого спеціаліста кандидата, пізніше доктора сільськогосподарських наук, професора М. В. Куксіна колишнього аспіранта Л. Г. Раменського (в Харкові він обіймав посаду завідувача відділу кормових ресурсів), в Інституті були започатковані і отримали значний розвиток дослідження 3 луківництва як важливої галузі сільського господарства. Невдовзі відділ було перетворено в координаційний осередок в Україні з питань лучного й польового кормовиробництва. В інституті була створена перша наукова школа луківників в країні, представники якої в подальшому поклали початок дослідженням з цієї галузі знань у багатьох інших науково-дослідних і навчальних установах республіки.

31974 р. до 2003 р. зазначений науковий підрозділ очолював автор цієї статті аспірант М. В. Куксіна й одночасно по Дніпропетровському національному університету під час навчання в ньому й подальшому співробітництву учень О. Л. Бельгарда видатного біогеоценолога та яскравого представника широко визнаної могутньої наукової школи «Д. І. Менделеєва - В. В. Докучаєва - Г. М. Висоцкого О. Л. Бельгарда». 32003 р. завідування відділом здійснює доктор сільськогосподарських наук, професор В. Г. Кургак (колишній аспірант і докторант А. В. Боговіна).

3 самого початку існування підрозділу, відповідаючи на запити виробництва щодо створення міцної кормової бази в господарствах, відділ розробив наукові основи з ряду актуальних питань докорінного і поверхневого поліпшення природних кормових угідь і болотних земель, випробував на цих угіддях широкий набір однорічних культур та багаторічних видів трав, розробив систему первинного передпосівного обробітку грунту і агротехніку їх вирощування. Багато уваги приділив розробці теоретичних принципів побудови лучних сівозмін та удобренню в них культур.

Ці дослідження, розпочаті у 1950 р. на Коростенському дослідному полі Інституту землеробства, згодом поширилися на різні типи природних кормових угідь і велися ще на Київській дослідній станції, в дослідному господарстві «Копилів» Інституту землеробства та колективному сільськогосподарському підприємстві «Степанське» Сарненського району Рівненської області (М. В. Куксін, М. Д. Новицький, А. С. Шкабара, 3. В, Морозова, Л. Л. Крапива, А. Г. Балан, С. О. Скуднова, К. І. Сайчук, О. М. Дзвоник, Г. М. Дубинська). Проведені дослідження показали, що запровадження сіяних лук чи сівба добре підібраних однорічних культур може в 3-5 і більше разів підвищити врожайність малопродуктивних лук. Доведено, що при господарській потребі однорічні культури на луках доцільно висівати лише на 
ерозійно безпечних родючих грунтах, переважно в лучних сівозмінах 3 польовим періодом від 2 до 5 і лучним - від 2-3 до 6 років. Прискорене залуження, тобто сівба трав одразу ж по свіжозібраній і добре розробленій дернині, забезпечує також високу урожайність, проте собівартість рослинної продукції порівняно 3 лучними сівозмінами у 4-5 разів менша та істотно зменшуються ризики прояву ерозії грунтів.

Серією дослідів 3 добору багаторічних травосумішей для сінокісного використання (М. В. Куксін, М. Д. Новицький) вже у 1940-1952 рр., на відміну від досить широко рекомендованих на той час складних сумішей 3 8-19 видів, була доведена доцільність застосування для короткочасного використання простих травосумішей з 1-2 видів бобових, 1-2 видів нещільнокущових і 1 виду кореневищних злаків. На родючих грунтах допускається сівба парних бобово-злакових сумішей, а на недостатньо осушених болотах - навіть одного злаку. Була доведена необов'язковість включення до складу сінокісних травосумішей низових злаків. Зроблена оцінка на луках різних видів добрив та показана їх позитивна роль в отримані високих врожаїв однорічних культур та багаторічних трав у системі лучних сівозмін і поза ними.

Одним із особливо важливих напрямів роботи відділу було вивчення типологічного складу природних кормових угідь. М. В. Куксіним ці роботи були розпочаті ще у 1932 р. в Українському науково-дослідному інституті прикладної ботаніки, пізніше реорганізованого в Інститут рослинництва (м. Харків). Уже в ті роки (1932-1934 рр.) при проведені за завданням Наркомзему колишнього Радянського Союзу першого туру робіт з інвентаризації природних кормових угідь держави Всесоюзним інститутом кормів ім. В. Р. Вільямса із залученням регіональних науково-дослідних та учбових закладів, відповідно до умов України під керівництвом М. В. Куксіна вперше була розроблена фітотопологічна класифікація лук, дана їх природна та виробнича характеристика, зроблено районування, визначені площі в адміністративних районах і накреслені заходи щодо поліпшення та раціонального використання лук. Зведені матеріали по Україні увійшли складовою частиною в узагальнені матеріали по Союзу.

У 1957-1958 рр. ця типологія природних кормових угідь була уточнена і за нею під методичним керівництвом відділу луківництва (М. В. Куксін) у 1957-1961 рр., як уже згадувалося вище, одночасно з обстеженням грунтового покриву України було здійснено суцільне великомасштабне геоботанічне та культуртехнічне обстеження сінокісно-пасовищних угідь, стосовно кожного господарства складені плани типів природних кормових угідь та картограми щодо їх поліпшення, які були широко використані директивними і господарськими органами при плануванні та реалізації робіт 3 підвищення ефективності використання земельних ресурсів країни. У виконанні цієї роботи брали участь працівники, які потім стали науковими співробітниками чи аспірантами відділу луківництва (І. О. Паламарчук, А. В. Боговін, Л. М. Сипайлова, А. Й. Якименко, І. Ю. Валюшкевич).

У наступні роки в лабораторії були поглибленні дослідження 3 вивчення природних особливостей лучних угідь та 3 удосконалення методичних підходів і принципів їх класифікації. На підставі використання методологічних принципів вивчення об'єктів як складних систем, було теоретично обгрунтовано i запропоновано екосистемне тлумачення лук і розроблені нові підходи до їх типізації, сутність яких полягає в політетичній (комплексній) індикації еколого-флористичних ознак рослинності і особливостей грунтів лук як цілісних систем. Розроблена класифікація лучних екосистем, а для Полісся і північної частини Лісостепу України ідентифіковані площі їх основних груп, які дозволяють повніше визначити потенційні можливості сінокісно-пасовищних угідь і диференціювати рекомендації відповідно до їх типологічного складу (А. В. Боговін), разом 3 Інститутом землеустрою УААН була удосконалена методика та здійснено для всіх зон України бонітування грунтів природних кормових угідь. 
Відділ багато уваги приділяв і приділяє розробці технології створення і використання культурних пасовищ як важливої основи рентабельного ведення галузі тваринництва.

Розробка цієї проблеми в Інституті, зокрема на Козаровицькій дослідній станції луківництва, розпочалася ще у 1929 р. М. С. Данилевською і $з$ деякими перервами на цій станції велася до 1940 р. Основними питаннями в той час було вивчення ефективності загінної системи випасання пасовищ та заходів догляду за ними. Дослідженнями було доведено, що застосування загінного випасання порівняно 3 безсистемним збільшує продуктивність пасовищ на 20-30, а повноту використання травостою - на 30 \% і більше, добре зберігає вихідну еколого-біологічну структуру травостою.

Після утворення відділу луківництва під науковим керівництвом М. В. Куксіна роботи з питань створення й використання пасовищ відновились на цій станції в 1958 р. (Л. Л. Крапива, І. О. Паламарчук), а в 1959 р. із здійсненням широкої програми досліджень були закладені виробничі культурні пасовища в колишньому дослідному господарстві «Копилів» (спочатку на площі 90, а потім - 180 га), які швидко перетворились у полігон їх широкої популяризації в Україні. У цей період детально були вивчені способи створення культурних пасовищ на різних типах природних кормових угідь, підсів високоврожайних трав у природні та старосіяні травостої, строки початку випасання пасовищ після їх залуження (I. О. Паламарчук), пасовищні травосуміші (А. В. Боговін), дози, співвідношення і строки внесення мінеральних добрив та мікроелементів (А. В. Боговін, А. Й. Якименко, В. М. Тітова, Л. Ф. Харитоненко, Т. О. Жданова). Встановлено значення підгодівлі корів та ремонтного молодняка великої рогатої худоби при утримані їх на пасовищах (Ф. І. Очеретько). Одночасно під керівництвом відділу розробка технологічних основ створення та використання культурних пасовищ проводилася i в інших господарствах - щодо добору травосумішей і системи удобрення їх на Київській дослідній станції Інституту землеробства (Л. Л. Крапива), державному сільськогосподарському підприємстві «Поліське» Макарівського району Київської області (О. М. Клецький), щодо способів створення сіяних пасовищ на піщаних грунтах - у колективному сільськогосподарському господарстві «Грозинське» колишньої Житомирської державної обласної сільськогосподарської дослідної станції (Г. П. Левчук, М. Ф. Давидюк). Все це дозволило створити міцну базу, яка мала визначальний вплив на розвиток наукових досліджень та стан пасовищної справи в Україні. Культурні пасовища за підтримки держави були створені в багатьох господарствах і загальна їх площа вже у 1978 р. становила 550 тис. га.

Вперше в Україні відділ розробив наукові основи та технологію створення і використання зрошуваних культурних пасовищ очищеними промислово-побутовими стічними водами (О. І. Паламарчук, М. В. Куксін, А. В. Боговін, В. Ф. Максименко, Й. К. Копистеринський). Розпочавши дослідження одночасно зі створенням в радгоспі «Бортничі» Бориспільського району Київської області господарського пасовища на площі 500 га для утримання 1000 корів і 300 голів молодняка, вперше в колишньому Союзі і в світі було відпрацьовано і впроваджено у виробництво систему комбінованого поєднання великих загонів (по 20-25 га в одному масиві) із щоденним порційним випасанням високоудійних корів (4,5-5 тис. кг і більше молока на корову) великими гуртами - 500-600 голів у гурті, систему догляду за пасовищем, ïх зрошення й використання як джерела пасовищних i зимових кормів. Під час XII Міжнародного конгресу з луківництва, який відбувся 11-20 червня 1974 р. в Москві, найвідоміші вчені-луківники з провідних пасовищних країн - Голландії, Великої Британії, Нової Зеландії, Німеччини, США та ін. наукову роботу i розроблену виробничу модель зрошуваного пасовища віднесли до найкращих зразків світового рівня. 
Пізніше (1982-1986 рр.) на базі дослідного господарства «Копилів» вагомий внесок зроблено в удосконалення системи зрошення лукопасовищних угідь чистими водами, режимів зрошення та методів визначення строків поливу угідь за метеоданими (А. В. Боговін, В. Г. Кургак, В. Г. Олефір).

Відділ провів вагомі дослідження 3 розробки технології створення високопродуктивних сіяних багатоукісних травостоїв, ефективного використання в луківництві потенціалу бобових трав як джерела біологічного азоту та чинників підвищення білковості й енергонасиченості кормів. Відділу належить пріоритет в Україні у розробці лучних конвеєрів на основі різностиглих злакових та бобово-злакових траво- і сортосумішей з періодом безперервного надходження високоякісної рослинної маси на сінокосах впродовж 135, пасовищах - 150-160, а у поєднанні 3 однорічними холодостійкими культурами ранньовесняного та пізньоосіннього строків використання 200-220 днів (А. В. Боговін, В. Г. Кургак, В. М. Тітова, Т. В. Кончакова, А. М. Левковський, О. М. Давидюк). Вперше в Союзі розроблено пасовищний конвеєр на базі лише багаторічних трав із залученням резервних загонів з ними, який не тільки забезпечує безперервне надходження свіжої рослинної маси для худоби впродовж 200-220 днів у вегетаційний період, а й істотно підвищує повноцінність пасовищного корму та на 17-25\% порівняно з існуючими моделями конвеєрів зменшує витрати матеріально-енергетичних витрат на його створення й використання (А. В. Боговін, С. В. Дудник, Р. М. Кулик). Для бобово-злакових травосумішей встановлено найкращий видовий і сортовий склад бобових трав та їх вплив на накопичення біологічного азоту та рівні компенсації ним азоту мінеральних добрив, виявлені кращі способи розміщення та норми висіву насіння компонентів у сіяних ценозах, режими використання травостоїв. Для основних видів трав уточнено екологічні та фітоценотичні оптимуми, ступінь їх біологічної сумісності в ценозах залежно від типів лук, різних рівнів удобрення та інтенсивності використання. На цій основі удосконалено принципи добору та видовий склад травосумішей і дано їх районування для умов Полісся і Лісостепу України. 3'ясована ценозо-формативна та господарська роль збагачення простих травосумішей представленням кожного виду в них не одним, а трьома сортами в підвищенні продуктивності травостоїв та їх стійкості за роками (А. В. Боговін, В. О. Сацик, М. В. Сукайло).

Досліджена i запропонована виробництву система удобрення багатоукісних сінокосів (А. В. Боговін, В. Г. Кургак, А. М. Левковський, В. І. Лещенко, Ю. В. Лещенко) і вперше в Україні для різних зон та типів лук розроблені нормативні критерії внесення мінеральних добрив. Установлені прирости урожайності, визначені виноси і коефіцієнти використання поживних речовин із грунту та мінеральних добрив, які дозволяють підвищити ефективність застосування на луках мінеральних добрив шляхом більш раціонального їх використання за природно-кліматичними регіонами, встановлювати дози, здійснювати ресурсне прогнозування продуктивності лукопасовищних угідь (А. В. Боговін, В. Г. Кургак). Розроблено функціональні моделі їх ефективного застосування для різних типів природних кормових угідь (В. Г. Кургак, А. М. Левковський).

Великий обсяг досліджень проведено з питань розробки технології поліпшення низинних, заплавних лук з природним травостоєм, в тому числі й довгозаливних, як потенційно найбільш цінних для організації на них високоефективного лучного кормовиробництва.

Розробка цього напрямку досліджень в Інституті розпочата ще у 1924-1930 pp. 3. М. Кашиним, а в 1938-1940 pp. - 3. М. Кашиним та Я. Я. Чумаковим на заплавних луках Дніпра Козаровицької дослідної станції луківництва. В той час тут вивчали дію мінеральних добрив, вплив ранньовесняного та пізньоосіннього строків випасання і боронування на продуктивність лук.

У 1960 р. А. В. Боговіним у ДСП «Заповіт Леніна» (колишній колгосп) Баришівського району Київської області, а в 1983-1985 pp. А. В. Боговіним і В. П. Хоменком в КСП «Нива» (колишній колгосп «30-річчя Перемоги») 
Борзнянського району Чернігівської області проведені дослідження 3 поверхневого поліпшення низинних засолених луків з содово-солончакуватими грунтами, процесам содоутворення i вторинному засоленню яких свого часу багато уваги приділив видатний знавець грунтів України і талановитий наставник наукової молоді Г. М. Самбур (безпосередній учень корифея вітчизняного грунтознавства Г. Г. Махова). Практично вперше була з'ясована роль різних доз азотних, фосфорних і калійних добрив та ї поєднань у трансформації видової структури та підвищенні продуктивності природних ценозів лучно-галофільного комплексу. Тут же були встановлені й найкращі травосуміші для цього типу лучних угідь.

Перші грунтовні дослідження з проблем поліпшення природних довгозаливних заплавних лук були проведені в 1967-1970 рр. в заплаві Десни в ДСП ім. Кірова Броварського району Київської області (М. В. Куксін, І. О. Паламарчук, А. В. Боговін, О. О. Ловчиков, Т. В. Кончакова). У наступні роки вони були продовжені спочатку в радгоспі «Бортничі» (1972-1977 pp.), а з 1987 р. до 2003 р. - в ДСП «Дніпровське» Бориспільського району цієї області, яке в 1977 р. за участю відділу було включено разом 3 іншими придніпровськими господарствами до складу міжгосподарського агропромислового підприємства 3 виробництва різних видів кормів на заплавних луках Дніпра (М. В. Куксін, А. В. Боговін, О. М. Дзвоник, Й. К. Копистеринський, С. В. Дудник, Р. М. Кулик).

Тут всебічно вивчені дози, строки внесення мінеральних добрив за сінокісного і пасовищного використання, вплив їх, а також зрошення, вапнування, підсіву трав, режимів скошування в системі сінокосозмін чи поза ними, біостимуляторів росту рослин та асоціативних азотфіксуючих мікроорганізмів на видовий склад ценозів та динаміку біогенних елементів у грунті і рослинах, екологічний стан лучних екосистем. Проведені дослідження щодо добору травосумішей. В умовах тривалого затоплення відпрацьована система створення і використання культурних пасовищ.

В останні десятиліття в зв'язку з реформуванням земельного фонду країни й усуненням надмірної його розораності, яка сильно порушила структуру просторовофункціональної організації аграрних територій у напрямі невиправданого збільшення в них деструктивних складових і спричинила небувалого погіршення екологічного стану ландшафтів і життєвого середовища, в відділі Інституту значна увага приділена фундаментальному вивченню та розробці ефективних способів відтворення на вилучених з тривалого інтенсивного обробітку у сівозмінах малопродуктивних орних землях постійних саморегулюючих трав'янистих екосистем i ïx зонально обумовленого природного біорізноманіття як найважливішої ресурсної бази біосфери й форми існування на планеті живої матерії. В результаті встановлено фітогенетичні процеси формування еколого-біологічної структури спонтанно відновлюваних ценозів, їх продуктивність, якісні показники рослинної продукції, а також вплив різних агротехнічних заходів - стартового підсівання селекційних і дикорослих видів багаторічних трав, удобрення, режимів використання на прискорення темпів проходження сингенетичних змін й підвищення їхньої природоохоронної i господарської цінності (А. В. Боговін, М.М. Пташнік).

В результаті встановлено, що спонтанне відтворення на таких землях зональних екосистем $є$ складним та досить тривалим динамічним у просторі і часі єдиним процесом сингенезу, що складається із серії тимчасових, послідовно змінюваних за детермінантно-хаотичним типом розвитку динаміки стадій заростання, кожна 3 яких характеризується своєрідною видовою, еколого-біоморфологічною, флористикоіндивідуалістичною та фітоценотичною структурою рослинних угруповань i особливим станом біорізноманіття. Будь-яка попередня стадія $\epsilon$ підготовчим етапом і головною ресурсною базою становлення наступної, а таксономічне багатство й рівень функціональної гармонізованості біологічного різноманіття - визначальним показником iï стану та енергетичного потенціалу динамізму і механізмів його реалізації. За цього способу відновлення навіть у гумідній зоні він триває близько 
17-20 pр. Посів на початковому етапі відновлення простих бобово-злакових чи навіть злакових сумішей уже з 1-2 років життя істотно підвищує продуктивність систем, майже повністю усуває в сингенетичному ряду чужорідну бур'янисту фазу переважно 3 одно- та дворічних рослин і докорінно підвищує кормову цінність травостою, а додавання до сумішей ще й аборигенних представників дикорослої флори значно (на 5-7 років) прискорює формування багатовидових фітоценозів 3 високою самовідновлювальною здатністю, максимально наближених за видовою та еколого-біологічною структурою до первозданних природних екосистем.

Певний внесок зроблено в з'ясування нормативних параметрів структурнофункціонального стану біорізноманіття як невід'ємної й найвизначальнішої складової частини будь-яких еколого-біологічних систем у здійснені матеріальноенергетичних потоків i реалізації механізмів в них життєзабезпечуючих відновлюваних процесів. На базі врахування сучасної синантропізації довкілля розроблена класифікація стану (типи категорій порушеності) біорізноманіття та визначені основні напрями іiі оптимізації (Bogovin, 2011).

Істотно розширена методична база проведення теоретико-прикладних i фундаментальних системних досліджень природних i антропогенних утворень. Розроблені і запроваджені в дослідження природних явищ методи фізіогномічного та флористико-індивідуалістичного аналізу екологічних систем 3 широким залученням функціонально-групових оцінок біоморфологічних, ритмічних, екологічних, трофічних i інших властивостей біотичних комплексів чи їх складових частин (Bogovin et al., 2003), показники гемеробності біоти, тобто генетико-фізіологічних реакцій іiі на окультуренність чи антропогенне порушення умов існування (Bogovin, 2013; Bogovin and Ptashnik, 2013). Останнє має винятково важливе значення особливо для агротрансформованих і техногенно перетворених екологічних систем та оцінки їхнього біорізноманіття, оскільки цей напрям аналізу дозволяє встановити не тільки ступінь їх порушеності (деструкції), а й допустимі пороги антропогенного на них навантаження, що в умовах стрімкого зростання на довкілля такого тиску набуває надзвичайно великого народногосподарського й загально екологічного значення. Поряд 3 цим, постійно проводиться робота 3 визначення екоценобіотичного статусу рослин первинних оціночних одиниць в складі реалізації функціонально-групових та інших методів дослідження біотичних комплексів. Враховуючи, що лучні, як і будь-які інші системи є відкритими і розвиваються за детермінантно-хаотичним типом динаміки 3 проявом у них високого ступеня випадкових чинників формування. Останнім часом у відділі кормовиробництва і луківництва звернено певну увагу на залучення в дослідний процес методу нелінійного аналізу систем, який за визначенням С. В. Чернишенка (Chernychenko, 2000), А. П. Травлєєва, Н. А. Білової (Travleyev and Belova, 2008), нині є новим і надзвичайно перспективним напрямом досліджень при вивчені складних еколого-біологічних об’єктів. Він добре гармонізується з внутрішньою процесуальною сутністю відкритих природних i антропогенних біотичних систем i найповніше розкриває детермінантну спрямованість їх розвитку.

Нині у відділі вирішуються проблеми органічного виробництва продукції, вирощування енергетичних культур (В. Г. Кургак, Г. В. Єфремова), розробляються принципи системно-збалансованого використання природних i антропогенно трансформованих екосистем як одиниць біосфери (А. В. Боговін, М. М. Пташнік).

Науковці відділу неодноразово галузь представляли на міжнародних конгресах 3 луківництва - у 1974 р. на ХІІ-му в Москві (М. В. Куксін, I. О. Паламарчук, А. В. Боговін) та у 1977 р. на XIII-му в Leipzig German Democratic Republic (А. В. Боговін, I. О. Паламарчук, М. В. Куксін), на конгресах Свропейської Федерації луківників - у 1971 р. на 4-х Генеральних зборах у Швейцарії (А. В. Боговін), у 1975 р. на 6-тих Генеральних зборах в Іспанії (А. В. Боговін), у 1985 р. на 8-их Генеральних зборах у Великобританії (А. В. Боговін), у 1990 р. на 13-их Генеральних зборах у Чехословаччині (А. В. Боговін, В. Г. Кургак), у 1992 р. на 14-их Генеральних зборах у 
Фінляндії (А. В. Боговін, В. Г. Кургак), у 2008 р. на 22-их Генеральних зборах у Швеції (В. Г. Кургак), у 2012 р. на 24-их Генеральних зборах у Польщі (В. Г. Кургак, А. В. Боговін), на симпозіумах - у 2007 р. на 7-х зборах з екології лук у Словаччині (А. В. Боговін, С. В. Дудник, М. М. Пташнік) і у 2011 р. 3 питань луківництва в Австрії (В. Г. Кургак).

З 1982 р. науковці відділу кормовиробництва і луківництва впродовж тривалого часу були членами робочої групи 3 проекту МАБ № 3 «Трав’янисті ландшафти, сінокоси й пасовища» програми ЮНЕСКО «Людина і біосфера» та програми ООН із сталого розвитку України (А. В. Боговін, 2001) та з 1999 р. проекту ФАО «Пасовищні ресурси Світу» 3 розроблення за такою назвою розділу, але в межах України (А. В. Боговін, С. В. Дудник). 32008 по 2012 рр. відділ на правах членства був представлений у виконавчому комітеті Європейської Федерації луківників, а зараз $є$ постійним представником в ній від України (В. Г. Кургак).

Відділ виконує велику роботу з підготовки наукових кадрів вищої кваліфікації: докторів і кандидатів наук з зазначеної галузі знань.

Національний науковий центр «Інститут землеробства НААН» Національної академії аграрних наук України i зокрема його відділ кормовиробництва i луківництва 3 часу свого утворення вніс і продовжує вносити значний вклад у становлення й подальший розвиток вітчизняного луківництва, в розробку фундаментальних і прикладних основ як однієї з важливих галузей знань та дієвого чинника впливу на підвищення ефективності подальшого розвитку одного 3 важливих напрямів науки й народного господарства держави.

\section{СПИСОК ЛІТЕРАТУРИ}

Bogovin, A. V., Travleyev, A. P., Belova, N. A., Dudnyk, S. V., 2003. Ecologichnyj analiz roslynnosti pryrodnych biogeocenoziv (phiziognomichni ta florystyko-indyvidualistychni aspekty analizu $\mathrm{v}$ ekologii) [The ecological analysis of vegetation natural biogeocenosis (Phisiognomy and floristicindividualistic aspects of the analysis in ecology)], Ecology and Noospherology, 13, 1-2, pp. 4-11 (in Ukrainian).

Bogovin, A. V., 2011. Tipy kategoriy bioraznoobraziya $\mathrm{v}$ usloviyah antropogennoy transformacii ekologicheskih system [Types of categories of biodiversity in the conditions of antropogenic transformation of the ecological systems], Ecology and Noospherology, 22, 3-4, pp. 73-83 (in Russian).

Bogovin, A. V., 2013. Otsinka stupenya porushennya phitoriznomanittya antropogennotransformovanyh ecosystem [Degree of phytodiversity disturbance of antropogenic transformed ecosystems assessment], Ecology and noospherology, 24, 3-4, pp. 5-15 (in Ukrainian).
Bogovin, A. V., Ptashnik, M. M., 2013. Vyznachennya stupenya porushenosti travyanystyh ecosystem zalezhno vid antropogennogo vplyvu [Assesment of anthropogenous violation of grassy ecosystems], Collection of scientific works of the National Scientific Center "Institute of Agriculture of NAAS", Edelveis, Kyiv, 1-2, pp. 145-151 (in Ukrainian).

Chernyshenko, S. V., 2005. Nelineynye metody analiza dynamiki lesnykh biogeocenozov [Nonlinear analusis of forest ecosystems dynamics], Dnipropetrovsk University Press, Dnipropetrovsk (in Russian).

Sayko, V. P., 2000. Institutu zemlerobstva 100 [To the Institute of Agriculture - 100 years], News of agrarian science, Special issue, May, pp. 5-11 (in Ukrainian).

Travleyev, A. P., Belova, N. A., 2008. Les kak faktor pochvoobrazovaniya [Forest as soilforming factor], Gruntoznavstvo, 22, 3-4, pp 6-26 (in Russian). 